\title{
JA/N/2610Mm 093624
}

\section{K Compressive Properties of Directionally Solidified Ni-33Al-33Cr-1Mo}

\section{J. Daniel Whittenberger ${ }^{1}$, S.V. Raj ${ }^{1}$, and Ivan. E. Locci ${ }^{2}$}

${ }^{1}$ NASA-Glenn Research Center, Cleveland, OH 44135, John.D.Whittenberger@grc.nasa.gov

${ }^{2}$ Case Western Reserve University at the NASA-Glenn Research Center, Cleveland, OH 44135

\section{ABSTRACT}

The Ni-33Al-33Cr-1Mo eutectic has been directionally solidify by a modified Bridgeman technique at growth rates ranging from 7.6 to $508 \mathrm{~mm} / \mathrm{h}$ to produce grain/cellular microstructures containing alternating plates of $\mathrm{NiAl}$ and $\mathrm{Cr}$ alloyed with $\mathrm{Mo}$. The grains had sharp boundaries for slower growth rates $(\leq 12.7 \mathrm{~mm} / \mathrm{h})$, while faster growth rates $(\geq 25.4 \mathrm{~mm} / \mathrm{h})$ lead to cells bounded by intercellular regions. Compressive testing at $1300 \mathrm{~K}$ indicated that alloys DS'ed at rates between 25.4 to $254 \mathrm{~mm} / \mathrm{h}$ possessed the best strengths which exceed that for the as-cast alloy.

\section{INTRODUCTION}

Directional solidification (DS) of NiAl-X systems has shown promise for the simultaneous improvement of elevated temperature strength and room temperature toughness [14]. In general it was believed that these benefits could only be possible when the structure was perfectly aligned and fault free. Unfortunately such ideal microstructures tend to demand very slow grow rates which would be impracticable for commercialization. To determine if faster growth rates could produce materials with acceptable elevated temperature strength properties, the eutectic system Ni-33 Al-33Cr-1Mo (at \%) has been directionally solidified at rates ranging from 7.6 to $508 \mathrm{~mm} / \mathrm{h}$. This system was chosen since it forms a lamellar eutectic microstructure [1-3] comprised of $\mathrm{NiAl}$ and $\mathrm{Cr}$ alloyed with $\mathrm{Mo}\{\mathrm{Cr}(\mathrm{Mo})\}$ which has demonstrated a room temperature toughness of $17.3 \mathrm{MPa} \cdot \sqrt{\mathrm{m}}[3]$. This paper presents the alloy chemistry, microstructure and $1300 \mathrm{~K}$ compressive behavior for both as-cast and directionally solidified materials. Compression was utilized to determine mechanical properties because of the ease of machining and testing specimens and the measurement of identical $1300 \mathrm{~K}$ compressive and tensile flow stress - strain rate properties in several DS'ed NiAl-X systems $[5,6]$.

\section{EXPERIMENTAL PROCEDURES}

A detailed discussion of the techniques employed to produce directionally solidified rods of $33 \mathrm{Ni}-33 \mathrm{Al}-33 \mathrm{Cr}-1 \mathrm{Mo}$ is presented in refs. 4 and 6 . In short, $19 \mathrm{~mm}$ diameter as-cast alloy bars were prepared by induction melting in $\mathrm{Al}_{2} \mathrm{O}_{3}$ crucibles and casting into a copper chill mold. Such bars were then placed in high purity alumina open-ended tubes for directional solidification in a modified Bridgeman apparatus under flowing high purity argon. Preferential solidification was accomplished by pulling the tube through a hole in a fixed position water-cooled copper baffle which yielded thermal gradients at the liquid/solid interface of about $8-10 \mathrm{~K} / \mathrm{mm}$. A total of seven DS'ed rods were produced at growth rates of 7.6, 12.7, 25.4, 50.8, 127, 254 and 508 $\mathrm{mm} / \mathrm{h}$. Samples for chemistry and metallography examination were taken from each as- cast bar as well as the aligned region of each DS'ed rod. Chemical analysis to determine both major and minor solute metallic elements was performed by an inductively coupled plasma (ICP)

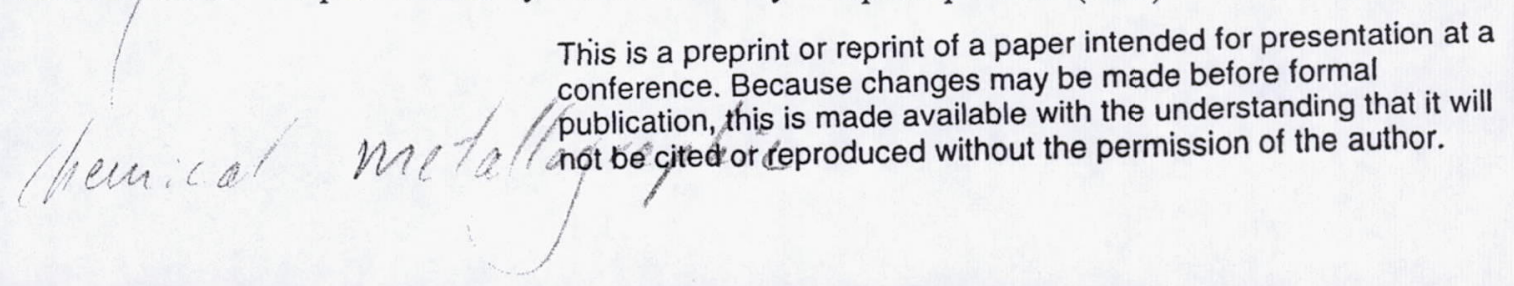


technique. The concentrations of nitrogen and oxygen were determined by an inert gas fusion method, while the carbon level was measured by the combustion extraction method. Transverse and longitudinal sections of selected as-cast bars and all seven DS'ed rods were metallographically prepared and examined by light optical techniques.

Parallelepiped compression samples $8 \times 4 \times 4 \mathrm{~mm}$ in size with the long axis parallel to the casting or DS growth direction were electrodischarge machined from several as-cast bars and the aligned region of each DS'ed rod. Both constant load and constant velocity compressive testing was undertaken in air at $1300 \mathrm{~K}$. Lever arm test machines were utilized for constant load creep experiments, where deformation was determined as a function of time by measuring the relative positions of the ceramic push bars applying the load to the specimen. Constant velocity tests were conducted in a universal machine at crosshead rates ranging from $1.7 \times 10^{-2}$ to $1.7 \mathrm{x}$ $10^{-6} \mathrm{~mm} / \mathrm{s}$. All the acquired test data were normalized to the final specimen length, and true stresses, strains and strain rates were determined with the assumption of constant volume.

\section{RESULTS AND DISCUSSION}

Alloy Composition -- The average, maximum and minimum values and the standard deviation for $\mathrm{Al}, \mathrm{Cr}$ and $\mathrm{Mo}$ are reported for the as-cast bars and directionally solidified rods in Table 1.

Table. 1 Composition of as-cast and directionally solidified Ni-33Al-31Cr-1 Mo alloys

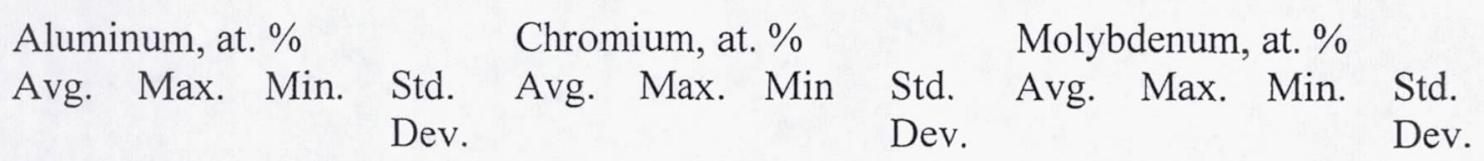

As-

$\begin{array}{lllllllllllll}\text { Cast } & 33.00 & 33.26 & 32.43 & 0.28 & 33.39 & 33.56 & 33.29 & 0.10 & 1.03 & 1.05 & 1.02 & 0.01\end{array}$

$\begin{array}{llllllllllll}\text { DS'ed } 32.85 & 33.71 & 31.21 & 0.68 & 33.47 & 34.90 & 32.88 & 0.54 & 1.02 & 1.04 & 0.99 & 0.016\end{array}$

The alloys also contained (at. \%) about $0.009 \mathrm{Cu}, 0.010 \mathrm{Fe}, 0.005 \mathrm{Si}, 0.07 \mathrm{C}, 0.002 \mathrm{~N}, 0.03 \mathrm{O}$ and $0.001 \mathrm{~S}$ as impurities. The results in Table 1 indicate the control of the alloy chemistry for all seven as-cast bars and DS'ed rods was quite good, and the average values are close to the intended Ni-33Al-31Cr-1Mo composition. While there is little change between the Mo levels in the as-cast and DS'ed alloys, surprisingly directionally solidification appeared to increase the difference between the maximum and minimum values for both $\mathrm{Al}$ and $\mathrm{Cr}$, and thus $\mathrm{Ni}$, over those measured in the as-cast bars. Such changes are, in turn, reflected by the larger standard deviations for the DS'ed rods.

Alloy Microstructure -- Photomicrographs illustrating the transverse structure of as-cast and DS'ed Ni-33Al-33Cr-1Mo are presented in Fig. 1. Relatively rapid solidification during casting into a $\mathrm{Cu}$-chill mold produced $\mathrm{NiAl}$ dendrites scattered among grains containing both $\mathrm{NiAl}$ and $\mathrm{Cr}(\mathrm{Mo})$ (Fig.1(a)). This can be compared to the regions (grains) of parallel $\mathrm{Cr}(\mathrm{Mo}$ ) and NiAl plates delineated by sharp boundaries (Fig. 1(b)) after DS'ing at $12.7 \mathrm{~mm} / \mathrm{h}$; cells enclosed by relatively thick intercellular regions where each cell contains lamella in a radial pattern (Fig. l(c)) after DS'ing at $127 \mathrm{~mm} / \mathrm{h}$; and cells containing $(\mathrm{Cr}, \mathrm{Mo})$ fibers which are surrounded by a thick, coarse structured intercellular border after DS'ing at $508 \mathrm{~mm} / \mathrm{h}$. The general appearance of the transverse microstructure in Fig. 1(c)) is typical of that found after DS'ing between 50.8 to 
$254 \mathrm{~mm} / \mathrm{h}$. The structure after the slowest growth rate $(7.6 \mathrm{~mm} / \mathrm{h})$ is similar to that shown in Fig. 1(b) except that occasional cells are partially composed of $\mathrm{Cr}(\mathrm{Mo})$ fibers.

In spite of some difference in chemistry among all the as-cast bars and DS'ed rods (Table 1), no third phases were found nor was there any evidence of $\mathrm{NiAl}$ or $\mathrm{Cr}(\mathrm{Mo})$ dendrites in the DS'ed regions. Overall the microstructures of the present $\mathrm{Ni}-33 \mathrm{Al}-33 \mathrm{Cr}-1 \mathrm{Mo}$ rods as a function of DS rate are similar to those found in $\mathrm{Ni}-33 \mathrm{Al}-31 \mathrm{Cr}-3 \mathrm{Mo}[4,7]$ as a function of growth rate. The structure in Fig. 1(b) is also in agreement with that for NiAl-32.4Cr-1Mo grown at 12.7 $\mathrm{mm} / \mathrm{h}$ by Cline, et al. [8] utilizing a Bridgeman technique. On the other hand Yang et al. [3] were able to maintain the sharp boundary cells comprised of the parallel plate type of microstructure (Fig. 1(b)) at growth rates of both 50 and $100 \mathrm{~mm} / \mathrm{h}$ in Ni-33Al-33Cr-1Mo through an Edge-defined Film-fed Growth method.

$1300 \mathrm{~K}$ Compressive Properties -- Examples of the compressive stress - strain curves obtained from constant velocity testing and the creep curves measured under constant load conditions are given in Fig. 2. The stress - strain curves (Fig. 2(a-c)) indicated that all materials underwent work hardening over the first one percent stain followed by continued flow at a more or less constant stress. As indicated by the two pairs of filled and open symbols in Fig. 2(b), testing under nearly identical conditions produced essentially the same stress-strain curves. Overall the constant velocity data (Figs. 2(a-c)) illustrate that $1300 \mathrm{~K}$ strength of the alloys decreases as the imposed deformation rate decreases, and at slower strain rates the as-cast material (Fig. 2(a)) is weaker than the DS'ed alloys (Fig. 2(b,c)). The creep curves for all the alloys (Fig. 2(d)) displayed normal behavior with work hardening during primary creep followed by steady state flow. This figure also illustrates the advantage of directional solidification, as like amounts of creep strain were accumulated over $\sim 600 \mathrm{ks}$ in spite of the much higher stresses on the two DS'ed alloys than on the as-cast material.

The $1300 \mathrm{~K}$ plastic flow stress - strain rate properties of as- cast and DS'ed Ni-33Al$33 \mathrm{Cr}-1 \mathrm{Mo}$ are presented in Fig.3, where flow strength was taken as the stress at $1 \%$ from the constant velocity test results (Fig. 2(a-c)) and the average stress over the steady state regime from the creep curves (Fig. 2(d)). The results from two as-cast Ni-33Al-33Cr-1Mo bars are presented in Fig. 3(a), and they illustrate that both bars possessed alike strengths. While all the flow stress - strain rate data (Fig. 3(b)) for the seven directionally solidified rods falls within a well defined band, visual examination of the results suggests that the properties of slowest (7.6 $\mathrm{mm} / \mathrm{h}$ ) and fastest $(508 \mathrm{~mm} / \mathrm{h})$ DS'ed rods were inferior to Ni-33Al-33Cr-1Mo DS'ed at intermediate growth rates. This contention was statistically tested utilizing an exponential stress law in combination with a dummy variable, where it was verified that $1300 \mathrm{~K}$ deformation characteristics of the rods DS'ed between 25.4 and $254 \mathrm{~mm} / \mathrm{h}$ were equivalent. This group of 4 rods was statistically superior in strength compared to that of the 7.6 and $508 \mathrm{~mm} / \mathrm{h}$ materials and marginally stronger than the rod DS'ed at $12.7 \mathrm{~mm} / \mathrm{h}$.

The $1300 \mathrm{~K}$ behavior of the best DS'ed rods of Ni-33Al-33Cr-1Mo are compared to the as-cast alloy in Fig. 4(a). This figure also illustrates the linear regression fits of the flow stress $(\sigma$ in $\mathrm{MPa})$ - strain rate $\left(\dot{\varepsilon}\right.$ in s $\left.\mathrm{s}^{-1}\right)$ data for both sets of material. Because of the log-log format of Fig. 4(a), the exponential fit for the DS'ed alloys, $\dot{\varepsilon}=3.13 \times 10^{-10} \exp (0.051 \sigma)$, shows curvature; whereas the power law description of the as cast alloy, $\dot{\varepsilon}=1.61 \times 10^{-18} \sigma^{6.00}$, is a straight line. Taken together the data show that directional solidification yields a very positive $(\sim 2 \mathrm{x})$ strength advantage over simple casting at strain rates $<10^{-5} \mathrm{~s}^{-1}$, but there is no advantage at faster deformation rates. 
As the $1300 \mathrm{~K}$ properties of DS'ed Ni-33Al-33Cr-1Mo are not dependent on growth rates ranging from 25.4 to $254 \mathrm{~mm} / \mathrm{h}$, changes in microstructual parameters, such as a refinement in interlamellar spacing, cell diameters and intercellular regions, are either unimportant or act in a manner to counter balance each other. In comparison to the previous study by Yang, et al. [3], structure could be important since testing of their planar eutectic Ni-33Al-33 Cr-1Mo at $\dot{\varepsilon}$ $\sim 5 \times 10^{-4} \mathrm{~s}^{-1}$ resulted in ultimate tensile strengths (UTS) of $420 \mathrm{MPa}$ at $1255 \mathrm{~K}$ and $348 \mathrm{MPa}$ at $1366 \mathrm{~K}$. Linear extrapolation of these results to $1300 \mathrm{~K}$ suggests a UTS of about $390 \mathrm{MPa}$ which is approximate $100 \mathrm{MPa}$ greater than the best flow stress measured in the current study (Fig. 3(b)). While a potential for improvement might exist, the curves in Fig. 4(b) reveal that the 1300 $\mathrm{K}$ slow strain rate compressive properties of the current DS'ed Ni-33Al-33Cr-1Mo are slightly better than those of DS'ed NiAl-34Cr and equivalent to those of DS'ed Ni-33Al-28Cr-6Mo [2].

In summary, we were able to reproducibly melt and cast Ni-33Al-33Cr-1Mo and directionally solidify this $\mathrm{NiAl}+\mathrm{Cr}(\mathrm{Mo})$ two phase eutectic by the Bridgeman technique at growth rates ranging from 7.6 to $508 \mathrm{~mm} / \mathrm{h}$. Compressive testing at $1300 \mathrm{~K}$ indicated that alloys DS'ed at rates between 25.4 to $254 \mathrm{~mm} / \mathrm{h}$ possessed the best strengths; hence it might be possible to produce materials with acceptable elevated temperature strength at a reasonably fast DS rate. Future work will concentrate on the 1200 and $1400 \mathrm{~K}$ compressive behavior to determine if the same dependency on growth rate is maintained; additionally the room temperature toughness of as-cast and DS'ed alloys will be measured to determine if an optimum combination of properties can be achieved.

\section{SUMMARY OF RESULTS}

Seven bars of Ni-33Al-33 Cr-1 Mo have been directionally solidified at rates ranging from 7.6 to $508 \mathrm{~mm} / \mathrm{h}$ which generally produced alternating plates of $\mathrm{NiAl}$ and $(\mathrm{Cr}, \mathrm{Mo})$ in grains with sharp boundaries $(\leq 12.7 \mathrm{~mm} / \mathrm{h})$ or cells surrounded by intercellular regions $(\geq 25.4 \mathrm{~mm} / \mathrm{h}$ ). Compressive testing at $1300 \mathrm{~K}$ indicated that rods DS'ed at rates ranging from 25.4 to $254 \mathrm{~mm} / \mathrm{h}$ had the best strength which, in turn, was substantially better than the properties of the as-cast alloy.

\section{REFERENCES}

1. J. L. Walter and H. E. Cline, Metall. Trans., 1 (1970) 1221-1229.

2. D.R. Johnson, X.F. Chen, B.F. Oliver, R.D. Noebe and J.D. Whittenberger. Intermetallics 3 (1995) 99-113.

3. J. M. Yang, S. M. Jeng, K. Bain and R. A. Amato, Acta Mater., 45 (1997) 295-305.

4. J.D. Whittenberger, S.V. Raj, I.E. Locci and J.A. Salem. Intermetallics 7 (1999) 1159-1168.

5. J.D. Whittenberger, R.D. Noebe, D.R. Johnson and B.F. Oliver. Intermetallics 5 (1997) 173-184.

6. S. V. Raj, I. E. Locci and J. D. Whittenberger, Creep Behavior of Advanced Materials for the $21^{\text {st }}$ Century (edited by R. S. Mishra, A. K. Mukherjee and K. Linga Murty), TMS, Warrendale PA, 1999, pp. 295-310.

7. S.V. Raj and I.E. Locci, "Microstructural Characterization of a Directionally Solidified Ni-33Al-31Cr-3Mo Eutectic Alloy as a fuction of Withdrawal Rate" submitted for publication. 8. H. E. Cline, J. L. Walter, E. Lifshin and R. R. Russell, Metall. Trans., 2 (1971) 189-194. 
Figure 1. Transverse microstructure of as-cast and directionally solidified NiAl-(Cr,Mo) eutectics. (a) As-cast Ni-33.1 Al-33.3Cr-1.03Mo, (b) Ni-32.16Al-34.06Cr-1.03Mo grown at 12.7 $\mathrm{mm} / \mathrm{h}$, (c) Ni-32.59Al-33.40Cr-1.04Mo grown at $127 \mathrm{~mm} / \mathrm{h}$ and $\mathrm{Ni}-32.86-33.30-1.03 \mathrm{Mo}$ grown at $508 \mathrm{~mm} / \mathrm{h}$. NiAl is the dark phase and $(\mathrm{Cr}, \mathrm{Mo})$ is the bright phase.

Figure 2. True compressive stress - strain curves as a function of strain rate from $1300 \mathrm{~K}$ constant velocity testing of Ni-33Al-33Cr-1Mo: (a) As-cast, (b) DS'ed at $25.4 \mathrm{~mm} / \mathrm{h}$ and (c) $D S$ 'ed at $508 \mathrm{~mm} / \mathrm{h}$; and true compressive creep curves from constant engineering stress creep testing of three forms of $\mathrm{Ni}-33 \mathrm{Al}-33 \mathrm{Cr}-1 \mathrm{Mo}$ : As-cast at $40 \mathrm{MPa}, \mathrm{DS}$ 'ed at $25.4 \mathrm{~mm} / \mathrm{h}$ at $70 \mathrm{MPa}$ and DS'ed at $254 \mathrm{~mm} / \mathrm{h}$ at 75 and $102 \mathrm{MPa}$.

Figure 3. True $1300 \mathrm{~K}$ compressive flow stress - strain rate behavior for $\mathrm{Ni}-33 \mathrm{Al}-33 \mathrm{Cr}-1 \mathrm{Mo}$. (a) two as-cast bars and (b) seven DS'ed rods as a function of growth rate.

Figure 4. Comparison of the $1300 \mathrm{~K}$ strength properties of the strongest DS'ed $\mathrm{Ni}-33 \mathrm{Al}-33 \mathrm{Cr}$ 1 Mo rods to those for the (a) As-cast alloy and (b) DS'ed NiAl-Cr(Mo) alloys [2]. 

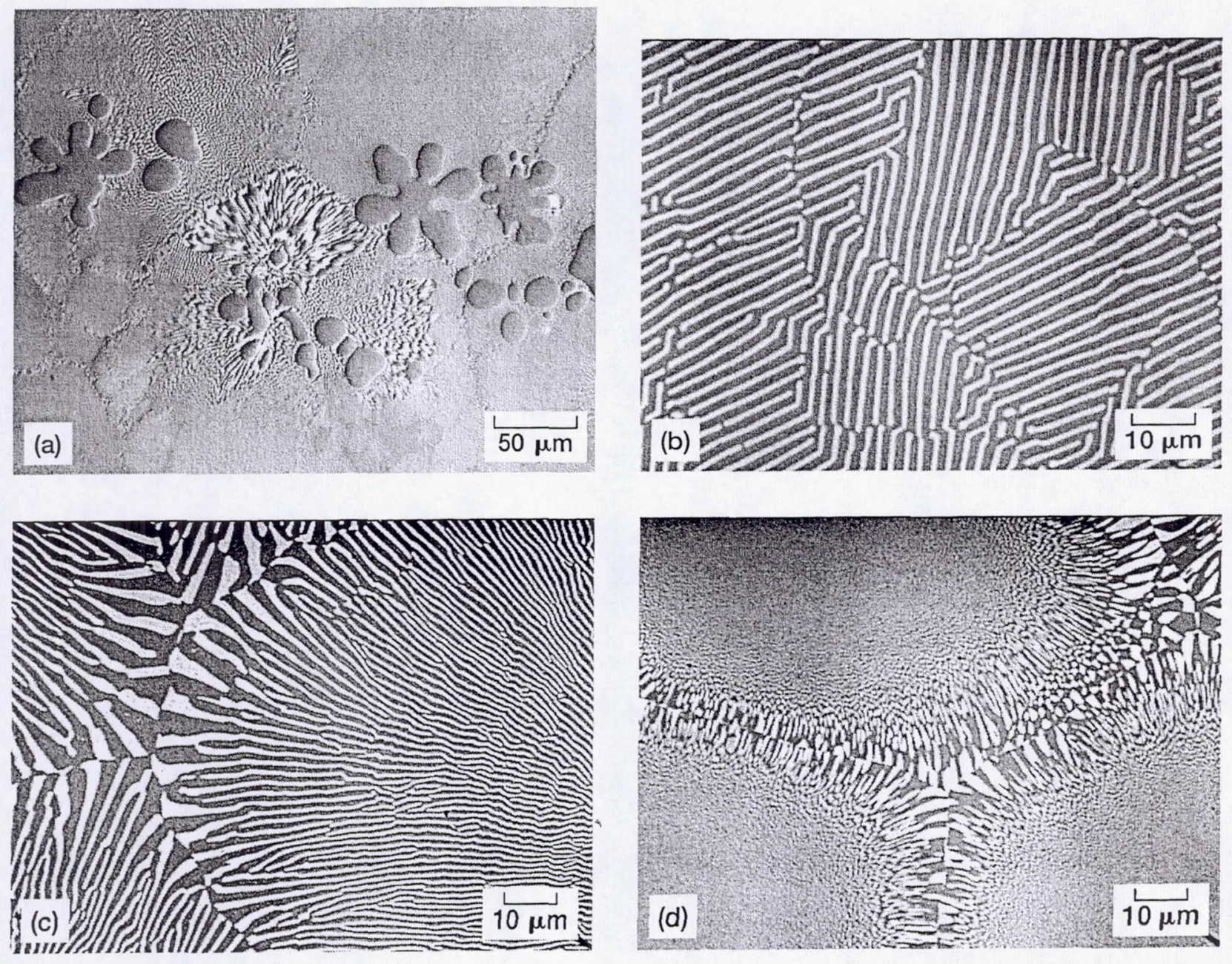

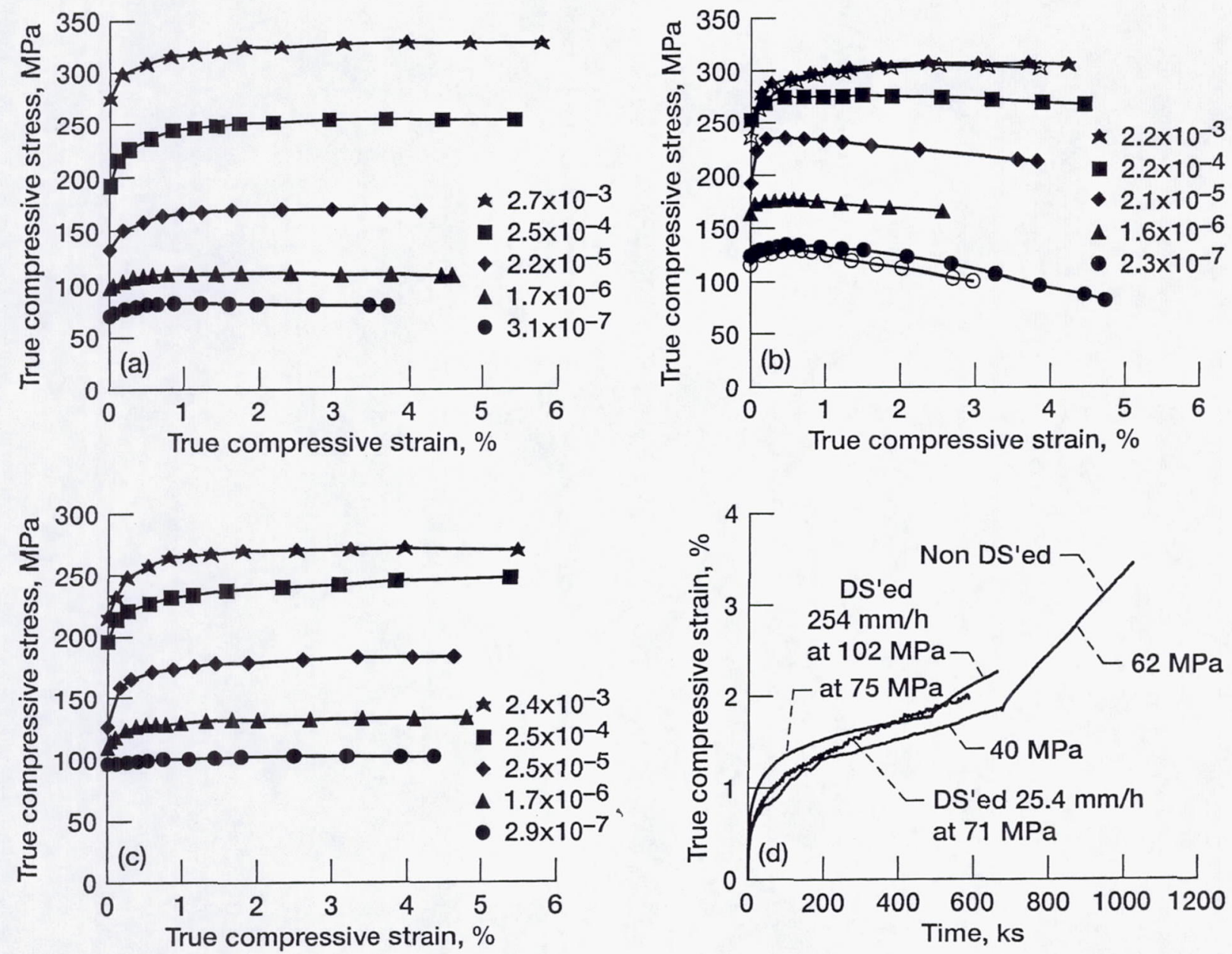

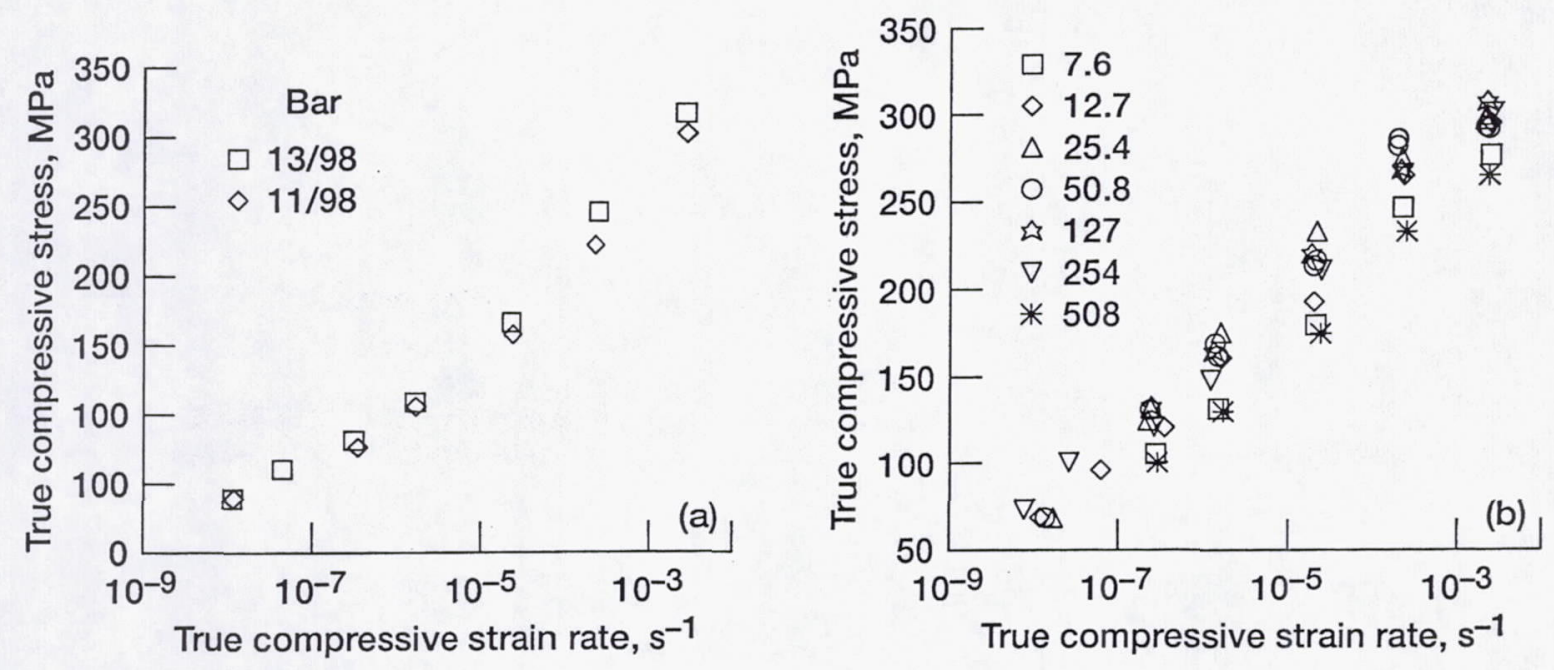

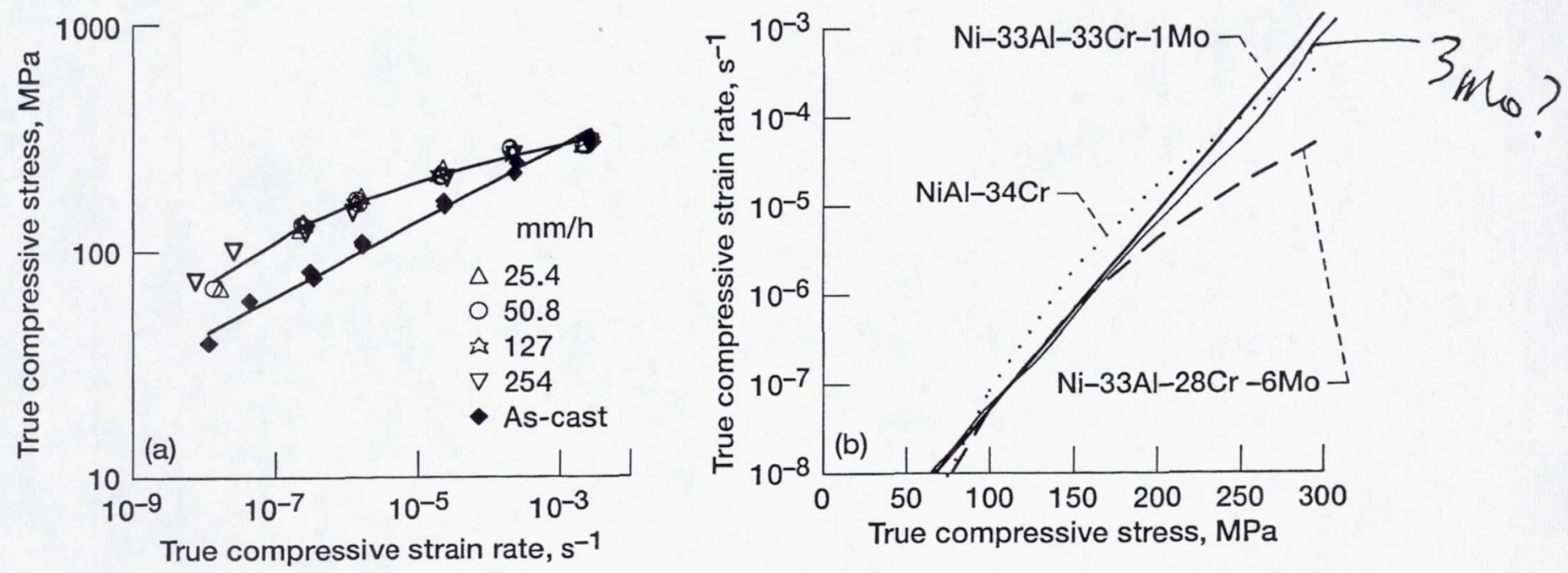